\title{
Uusia ominaisuuksia kasveihin geenitekniikan avulla
}

\author{
Viola Niklander-Teeri \\ Soveltavan biologian laitos, Latokartanonkaari 5-7, PL 27, 00014 Helsingin yliopisto, \\ viola.niklander-teeri@helsinki.fi
}

\begin{abstract}
Tiivistelmä
Ensimmäiset geeniteknisesti muunnellut (GM) kasvit raportoitiin 20 vuotta sitten. Siitä lähtien on siirtogeenitekniikkaa kehitetty ja käytetty hyväksi monien tärkeiden kasvilajien (mm. tärkeimmät viljakasvit) ominaisuuksien jalostamiseen. Aluksi ominaisuudet käsittivät erilaisia viljelyteknisiä parannuksia, joista tunnetuimmat ovat USA:n markkinoilla jo monta vuotta olleet hyönteisresistenssit maissilajikkeet ja rikkakasvihävitteitä kestävät soijalajikkeet. Seuraavan sukupolven siirtogeenisten kasvien arvoidaan hyödyntävän suoranaisemmin myös kuluttajaa, esimerkkeinä ovat terveellisemmät kasviöljyt, aminohappokoostumukseltaan parannetut ruokakasvit sekä lääkeaineiden tuotto kasveissa. Ehkä kuuluisin esimerkki tällä hetkellä kehitteillä olevasta toisen sukupolven GM-kasvista on ns. 'Kultainen riisi', joka on kehitetty geeniteknisin menetelmin tuottamaan A-vitamiinin esiastetta, betakaroteenia (estää mm. sokeutumista) riisissä, joka on tärkein ravintokasvi monissa Aasian köyhissä maissa. Tammikuussa 2001 IRRI (International Rice Research Institute) Filippiineillä aloitti Kultaisen riisin kehittämisen paikallisiin viljelysolosuhteisiin sopivaksi risteyttämällä sitä paikallisiin riisilajikkeisiin ja testaamalla sitä kenttäkokeissa. Kolmannen sukupolven GM-ominaisuuksien arvioidaan tulevaisuudessa liittyvän $\mathrm{mm}$. kasvin parannettuihin yhteyttämis- ja ravinteiden sitoutumiskykyihin.

Vaikka siirtogeenitekniikka kasvinjalostuksessa on jo pitkälle kehitetty ja käytetty menetelmä USA:ssa, on sen käyttöön Euroopassa suhtauduttu varauksella. Varauksellisuus johtuu ennen kaikkea siitä, että eräät EU:n jäsenvaltiot haluaisivat selkeästi jäljittää ja merkitä GM-tuotteet, saada lisätietoa GM-tuotteiden pitkäaikasvaikutuksista ja parantaa kansalaisten kuulemista asiassa. Tästä johtuen Euroopassa ei ole hyväksytty viljelyyn tai käyttöön yhtään uutta GM-tuotetta vuoden 1998 jälkeen (ns. de facto moratorium). Uuden direktiivin 2001/18/EY myötävaikutuksella jäljitettävyys ja merkintäasiat sekä kansalaisten kuuleminen GM-lupa-asioissa ovat selvästi parantuneet ja aikalisä on loppumassa. Lisäksi tutkimustietoa ja mielipidemittauksia on ehtinyt kertyä huikeasti lisää viiden vuoden aikana. Uusille tuotteille EU-viljelyyn ja EU-markkinoille onkin viime aikoina haettu kymmeniä lupia, niiden joukossa jo toisen sukupolvenkin GM-kasveja.
\end{abstract}

\section{Ensimmäisen sukupolven GM-kasvit: "BT-maissi" ja "RR-soija"}

Ensimmäiset laajamittaiset kaupalliset GM-kasvien viljelykset alkoivat vuonna 1996. Ensimmäisen sukupolven GM-kasvit olivat kestäviä eräiden tuhohyönteisten toukille (maissi ja puuvilla), rikkakasvihävitteille (soija, rapsi ja maissi) ja kasviviruksille (papaija ja kesäkurpitsa). Kaupallisten GM-kasvien viljelyn pinta-ala on noussut vuoden 1996 muutaman kymmenen tuhannen neliökilometrin alasta noin $700000 \mathrm{~km}^{2}$ (arvio 2003), joka vastaa noin kaksi kertaa Suomen pintaalaa (Kuva 1). Suurimmat GM-kasvien viljelijät ovat USA, Argentiina, Kanada ja Kiina, joista USA:n osuus on yli $65 \%$. Jo $80 \%$ soijasta, $70 \%$ puuvillasta ja $38 \%$ maissista on USA:ssa siirtogeenistä, osoittaen, että siirtogeenitekniikan käyttö on jo joidenkin kasvilajien ja -ominaisuuksien kohdalla todellista arkipäivää. Siirtogeenisten kasvien siemenmarkkinat ovat yli 3 miljardia dollaria. Euroopassa kaupallinen viljely on toistaiseksi ollut hyvin pienimuotoista.

Ensimmäiset markkinoille tulleet siirtogeenitekniikalla muutetut ominaisuudet liittyivät tuhohyönteisten ja rikkakasvihävitteiden kestävyyteen. Ns. Bt-maissi $(\mathrm{Bt}=$ Bacillus thuringiensis $) \mathrm{ja}$ RR-soija (RR=Roundup Ready $\left.{ }^{\circledR}\right)$ ovat esimerkkejä näistä. Bt-maississa kestävyyden hyönteisiä vastaan aiheuttaa maissiin siirretty Bacillus thuringiensis-maaperäbakteerin geeni, joka koodaa bakteerin Bt-toksiiniproteiiinia. Kun tuhohyönteisen toukka syö Bt-maissin lehteä, se saa toksiinia sisäänsä. Bt-toksiini kiinnittyy hyönteistoukan suolen reseptoreihin ja aiheuttaa toukan nälkiintymisen ja kuoleman. RR-soijassa kestävyyden rikkakasvihävitettä eli herbisidiä (glyfosaatti, tuotenimi Roundup $\left.{ }^{\circledR}\right)$ vastaan aiheuttaa soijaan siirretty Agrobacterium sp. -maaperäbakteerin EPSPS geeni. Se koodaa kasvin alkuperäistä EPSPS proteiinia kestävämpää EPSPS muotoa, jolloin rikkakasvihävite ei inhiboi EPSPS entsyymin toimintaa, joka tarvitaan välttämättömien aromaaattisten aminohappojen (tryptofaani, tyrosiini ja fenylalaniini) biosynteesin kasveilla ja bakteereilla. 


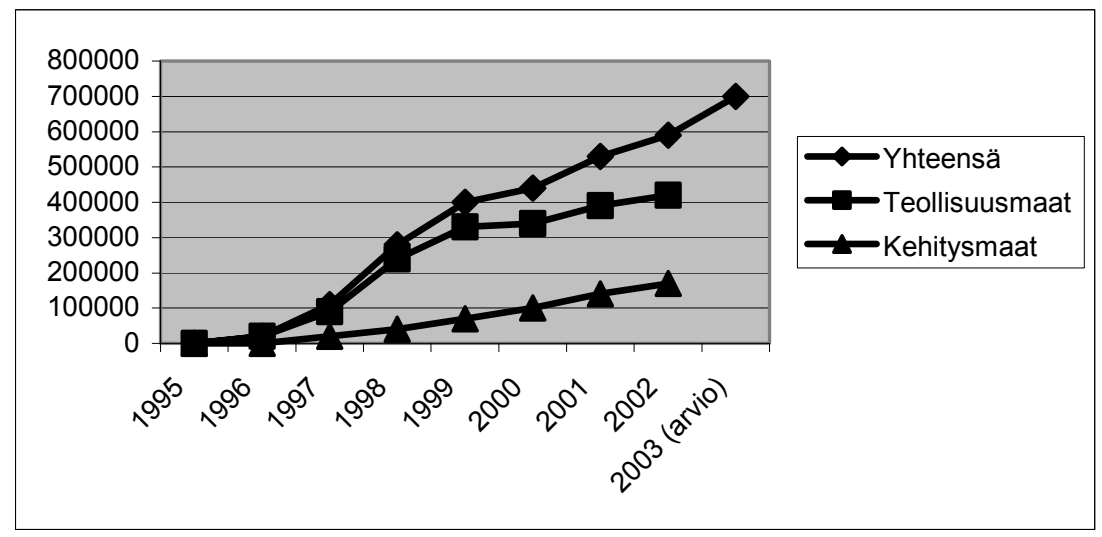

Kuva 1. GM-kasvien viljelyksien pinta-ala maailmanlaajuisesti 1996-2002 (km²) (mukaeltu ISAAA Brief, no 27, 2002)

\section{Toisen sukupolven GM-kasvien arvioidaan tulevan kaupalliseen tuotantoon 2005-2015}

Mitkä ominaisuudet sitten ovat seuraavat kohteet, joita kasveissa halutaan jalostaa? Esimerkit ovat moninaiset ja tutkimus ja kenttäkokeet ovat jo edenneet pitkällekin joidenkin kohdalla. Näitä uusia ominaisuuksia ovat esimerkiksi:

- ravintoarvoltaan parannetut kasvit (proteiinien, öljyjen, vitamiinien ja kivennäisaineiden parempi koostumus)

- hedelmien ja vihannesten parannettu säilyvyys

- kasvien parannetut maku- ja tuoksuominaisuudet

- kuivuuden, suolan, metallien ja lämpötilojen (kylmä/kuuma) kestävyyskyvyn parantaminen

- allergeenien poisto

- maanparannus kasvien avulla (engl. phytoremediation)

- kasvien käyttö hyödyllisten aineiden tuottajaisäntinä ("bioreaktoreina")

Näistä ominaisuuksista monet tulevat hyödyntämään jo suoraan kuluttajaakin. Esimerkiksi ravintoarvoltaan parannetut kasvilajikkeet ovat juuri niitä ominaisuuksia, mihin tänä päivänä tutkimuksessa ja tuotekehittelyssä haluttaisi keskittyä, kun pyritään jalostamaan terveellisempiä elintarvikkeita. Usein perinteinen risteytysjalostus ei kuitenkaan aina riitä ja avuksi tullaankin käyttämään enemmän ja enemmän genomiikkatutkimuksesta saatua suurta informaatiomäärää, jonka avulla kokonaisia metaboliareittejä pystytään selvittämään ja sen jälkeen muokkaamaan tiettyä osaa siitä (ks. alla).

Koska oma tutkimuksemme liittyy kasvien käyttöön bioreaktoreina (kasvissa tuotettavien syötävien rokotteiden kehittäminen), alla hieman tarkempi kuvaus siitä osa-alueesta.

\section{Kasvit bioreaktoreina}

Perinteisesti kasveja on käytetty ruoaksi, rehuksi, polttoaineeksi, rakennusaineeksi, kuidun lähteenä sekä erilaisiin lääkinnällisiin tarkoituksiin vuosituhansien ajan. Tulevaisuuden visioita on, että kasveja voitaisi käyttää ns. bioreaktoreina ("lääkeainetehtaina") tuottamaan vieraita proteiineja ja muita yhdisteitä (muita kuin kasvin omia) lääkinnällisiin tarkoituksiin. Esimerkkeinä tälläisistä lääkeainesta ovat rokotteet (antigeenit), vasta-aineet ja hormonit ja erilaiset terapeuttiset aineet. Tutkimuksen kohteena ovat $\mathrm{mm}$. hepatiitti-B:tä, erilaisia ripuleita (esim. kolera-bakteerin, ETEC:n ja Norwalkviruksen aiheuttamat), suu- ja sorkkatautia, hammasmätää ja sokeritautia vastaan kehitettävät lääkkeet kasvissa tuotettuna. Monet kehitteillä olevista lääkeaineita tuottavista GM-kasveista ovat jo laajamittaisissa kenttäkokeissa ja kliinisissä ihmiskokeissa. Ensimmäisten lääkeaineita tuottavien kasvien arvioidaan tulevan markkinoille muutaman vuoden päästä.

Kasvien käyttöön bioreaktoreina verrattuina muihin vaihtoehtoihin eli hiiva-, bakteeri- ja eläinsoluviljelmiin tai siirtogeenisiin eläimiin, on monta hyvää syytä, tässä yleisesti: 1) halvemmat pääoma- ja tuotantokustannukset, koska kasveja voidaan viljellä suuret määrät esim. pellolla ja käyttää hyväksi jo olemassa olevia maataloustekniikoita, kun taas muissa vaihtoehdoissa tarvitaan usein kalliita fermentoreita tai aseptisia solukkoviljelmiä; 2) kasveilla esim. siemeniä voidaan käyttää vieraiden proteiinien luonnollisena pitkäaikaissäilytyspaikkana, kun taas muissa vaihtoehdoissa 
tarvitaan usein kalliita kylmäsäilytysmuotoja, kuten pakastimia tai nestemäistä typpeä; 3) kasvit ovat turvallisempia, koska ne eivät ole isäntiä ihmispatogeeneille, kuten HIV:lle, prioneille tai hepatiittivirukselle; 4) eettiset ongelmat ovat pienempiä kun on kysymys kasvien valjastamisesta vierasproteiinien tuottoon verrattuna ennen kaikkea eläinten käyttöön "lääkeainetehtaina".

\section{Kolmannen sukupolven GM-kasvit (2015 jälkeen)}

Kolmannen sukupolven GM-kasvien ominaisuuksiin arvioidaan kuuluvan sellaiset, joiden tuottaminen perinteisin menetelmin on jo lähes mahdotonta. Tälläisiä ovat monet $\mathrm{mm}$. satoon liittyvät ominaisuudet:

- kasvin parannettu yhteyttämiskyky

- kasvin parannettu ravinteiden sitoutumiskyky orgaanisiksi yhdisteiksi (assimilaatio)

- hedelmien ja siementen määrän, koon ja laadun parantaminen

- kukkimisajan muutokset

- kasvin rakenteelliset muutokset

- heteroosin ja apomiksin hyötykäyttö

Nämä ominaisuudet ovat tyypillisesti sellaisia, joihin liittyy monien geenien koodaamia kokonaisia metaboliareittejä, eikä kaikkien komponenttien yhteensaattaminen ole enää mahdollista risteytys- tai mutaatiojalostuksella. Apuun on tullut uusi tieteen ala, genomiikkatutkimus, joka yhdistää kokonaisten genomien sekvenssoinnista saadun DNA-tason geenitiedon (engl. genomics) tietoon geenien toiminnasta (engl. functional genomics).

\section{Genomiikkatutkimus tarjoaa aivan uudet mahdollisuudet kasvinjalostukselle}

Genomiikkatutkimus on nopeasti kehittyvä tieteenala. Sen avulla on monen eliön koko genomin emäsjärjestys selvitetty (kasvigenomeista on jo kokonaan sekvenssoitu lituruoho ja riisi, tulossa ovat mm. maissi, ohra, vehnä, tomaatti, mailanen, peruna ja soija) ja geenien toimintaa ja säätelyä pystytty ensimmäistä kertaa tutkimaan kokonaisvaltaisesti. Kokonaisia metaboliareittejä ja niiden vuorovaikutusta muihin reitteihin pystytään arvioimaan samanaikaisesti ja sitä tietoa hyödyntämään suoraan kasvinjalostuksessa. Tieto geeneistä ja niiden toiminnasta mahdollistaa tulevaisuudessa tärkeiden biokemiallisten reittien "täsmämuokkauksen". Tämä tarkoittaa, että ensin selvitetään tarkoin esimerkiksi tietyn aineenvaihduntareitin toiminta geenitasolla ja sitten tätä tietoa hyväksi käyttäen muokataan toimintaa kohdennetusti (metaboliamuokkaus).

\section{Miksi GM-kasveja vastustetaan?}

Siirtogeenisistä kasveista on kertynyt erittäin paljon tutkimustietoa siitä lähtien, kun ensimmäinen geeninsiirto kasveihin vuonna 1983 julkaistiin. 80-luvun lopulla alkaneiden GM-kasvien kenttäkokeiden määrä on ollut kymmeniä tuhansia ja 1996 alkanut GM-kasvien kaupallinen viljely on tuottanut ruokaa sadoille miljoonille ihmisille. Näiden liki 20 vuoden aikana ei ole tullut esiin yhtään tapausta, jossa kaupallisessa tuotannossa olevat GM-kasvit olisivat aiheuttaneet vahinkoa ihmisen terveydelle tai ympäristölle. Kaupalliset GM-kasvit ovat myös paljon tiukemman tutkimuksen ja lainsäädännön alaisena kuin perinteisillä menetelmillä jalostetut kasvit. Sen vuoksi voidaankin sanoa, että ne ovat jopa luotettavampia, täsmällisempiä ja ennustettavampia kuin risteytyksellä tai mutaatioilla aikaansaadut lajikkeet. Koko siirtogeenitekniikkahan perustuu siihen, että ensin täytyy tietää tarkalleen kyseiseen ominaisuuteen vaikuttavat metaboliareitit ja niiden entsyymejä koodaavat geenit, jotta ne voidaan eristää ja käyttää geeninsiirron työkaluina. Siirtogeeniset kasvilinjat testataan laboratoriossa, kasvihuoneella ja kenttäkokeissa monen sukupolven ajan, jonka jälkeen parhaat linjat risteytetään eliittiviljelyslajikkeisiin ja niiden ympäristö/ekologia-, ravinto- allergia- toksisuus- ja muiden arvojen vaikutus testataan edelleen. Tutkijat ja viranomaiset pitävätkin kaupallisia GMlajikkeita vähintään yhtä turvallisina terveydelle ja ympäristölle kuin muilla menetelmillä markkinoille tuotettuja lajikkeita ja haluaisivatkin, että kokemuksen vielä kartuttua jonkin aikaa, GM-kasvien riskianalyysien ja lainsäädännön ei tarvitsisi olla yhtään sen erilaisempi kuin muidenkaan markkinoille tuotettujen kasvilajikkeiden.

Jos ympäristö- ja terveysasiat eivät ole ne todelliset uhat GM-tekniikan käytölle, miksi siirtogeenisiä kasveja sitten vastustetaan? Osittain syynä ovat olleet ne tapahtumat, jotka liittyivät GM-tekniikan käyttöönoton alkuaikoihin. Näitä olivat esim. se vääränlainen uho, jolla alussa ennustettiin GM-tekniikan korvaavan perinteisen jalostuksen ja olevan jotain täysin uutta. Tämä antoi väärän kuvan GM-tekniikasta luonnottomanan menetelmänä ja lisäksi vieraannutti kasvinjalostajat 
siitä. Muita syitä ovat olleet myös se tosiasia, että ensimmäiset sovellukset hyödyttivät lähinnä suuria yhtiöitä, jolloin tekniikka vieraantui heti tavallisesta kuluttajasta. Lisäksi kansalaisten ja kuluttajien kuuleminen oli alussa olematonta. Näihin yllämainittuihin syihin ollaan löytämässä vastaukset uusien kuluttajaläheisimpien tuotteiden tullessa markkinoille, pienten kasvibiotekniikkayritysten mukaantulon myötä ja kansalaisten kuulemisen järjestämisen myötä. Kaikesta huolimatta jäljelle jää vielä monenlaisia syitä vastustaa GM-tekniikkaa. Syyt voivat olla poliittisia, jotka liittyvät esim. monikansallisten yhtiöiden toimintaan GM-siemenkaupassa, kehitysmaiden huonoon asemaan, köyhyyteen, monopoleihin ja patentteihin, tai ne voivat liittyä ihmisten erilaisiin eettisiin arvoihin, kuten kulttuuri, etnisyys, uskonto, sosio-ekonomiset arvot, elämäntavat ja muut arvot. Varsinkaan viimeksi mainittuun eli arvosyihin ei voida, eikä tarvitsekaan vaikuttaa.

\section{Onko Suomella tulevaisuudessa jopa maantieteellinen etu GM-kasvien viljelylle?}

Usein puhutaan Suomen maantieteellisestä sijainnista haitallisena asiana, kun tarkastellaan sitä muihin EU-maihin nähden maanviljelysasioissa. Tämä varmasti pitääkin paikkansa monissa tapauksissa, kun verrataan perinteisen viljelyn kannattavuutta meillä ja Etelä-Euroopassa. On hienoa, että Suomen leveysasteilla pystytään tästä huolimatta jatkamaan kotimaista tuotantoa monilla viljelykasvilajeilla erityispanostuksen turvin.

Suomen maantieteellisella sijainnilla voidaan kuitenkin nähdä myös etuja tulevaisuuden maataloudessa. Visiona voisikin olla, että suomalaisella viljelijällä on hyvät mahdollisuudet erikoistua yhdistettyjen, siirtogeenisten ravinto- ja lääkekasvien tuotantoon pelloilla, kun perinteinen viljelytuotanto on siirtymässä meiltä etelämpään. Suomessa siirtogeenisten viljelykasvien avoin käyttö on turvallisempaa, koska melkein kaikki viljelykasvilajit ovat meillä tuontilajeja. Koska siirtogeenisillä viljelylajikkeilla ei ole risteytyviä lähisukulaisia täällä, eivätkä eliittilajikkeet selviä peltojen ulkopuolella luonnonvaraisena, geenien leviäminen luontoon minimoituu.

\section{Kirjallisuutta}

Brown, K. 2001. Genetically modified foods: are they safe. Scientific American, April 2001: 39-51.

Daniell, H., Streatfield, S.J. \& Wycoff, K. 2001. Medical molecular farming: production of antibodies, biopharmaceuticals and edible vaccines in plants. Trends Plant Sci 6: 219-226

Enriquez, J. 2001. Green biotechnology and European competitiveness. Trends Biotech 19: 135-139.

Fisher, R. \& Emans, N. 2000. Molecular farming of pharmaceutucal proteins. Transgenic Research 9: 279-299

Freckleton, R.P., Sutherland, W.J. \& Watkinson A.R. 2003. Deciding the future of GM crops in Europe. Science 302: 994-996.

Hoa, T.T.C, Al-Babili, S., Schaub, P., Potrykus I \& Beyer P. 2003. Golden Indica and Japonica rice lines amenable to deregulation. Plant Physiol 133: 161-169.

Kosuge, C.P., Merdith, A. \& Hollaender, (eds.). Genetic Engineering of Plants. An Agricultural Perspective. Plenum Press, New York

Lurquin, P.F. (ed.). 2002. High Tech Harvest: Understanding Genetically Modified Food Plants. Westview Press, USA.

Morandini, P. \& Salamini F. 2003. Plant biotechnology and breeding: allied for years to come. Trends Plant Sci 8: 70-75.

Nelson, G.C. (ed.). 2001. Genetically Modified Organisms in Agriculture. Academic Press, USA.

Oksman-Caldentey, K.M. \& Barz, W.H. (eds.). 2002. Plant Biotechnology and Transgenic Plants. Marcel Dekker, Inc., New York.

Toenniessen, G.H., O'Toole, J.C. \& DeVries, J. 2003. Advances in plant biotechnology and its adaptation in developing countries. Curr Opinion in Plant Biol 6: 191-198.

Vasil, I.K. 2003. The science and politics of plant biotechnology- a personal perspective. Nature Biotech 21: 849-851.

\section{Internet-viitteitä}

The International Service for the Acquisition of Agri-biotech Applications (ISAAA) kotisivu: http://www.isaaa.org/

Food and the Future- artikkelikokonaisuus. 2002. Nature 418: 667-707. www.nature.com/nature

EU:n GMO-tuotetiedotukset: http://gmoinfo.jrc.it/

Rinnakkaisviljely-ohjeita: http://europa.eu.int/comm/agriculture/publi/reports/coexistence2/guide_en.pdf

Geenitekniikan lautakunnan kotisivu: www.geenitekniikanlautakunta.fi

Biotekniikan neuvottelukunnan kotisivu: $\underline{\text { http://www.biotekniikanneuvottelukunta.fi }}$

Bioteknologia-info-projekti: http://www.bioteknologia.info/ 